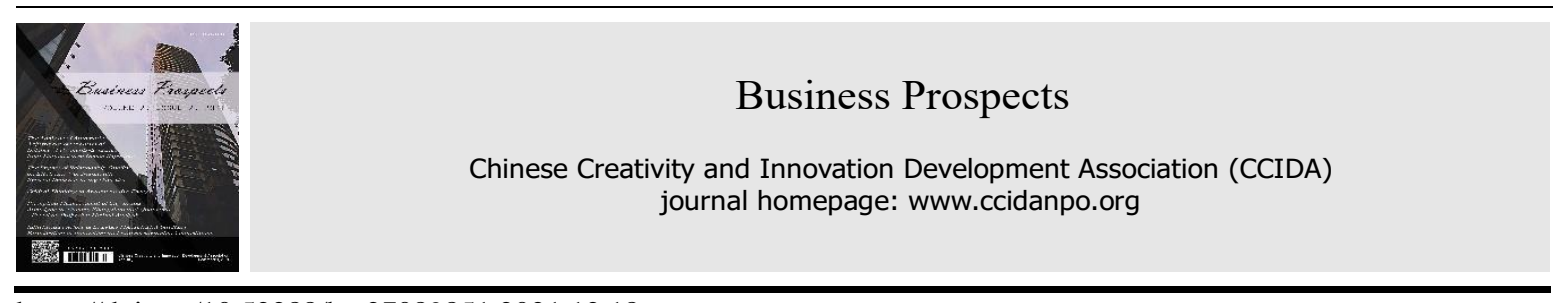

https://doi.org/10.52288/bp.27089851.2021.12.18

\title{
Analysis on the Situation of Tourists in Shanghai MICE Tourism Industry
}

\author{
Cheng-Yu He ${ }^{1, *}$ \\ ${ }^{1}$ School of International Business, Xiamen University Tan Kah Kee College \\ * Correspondence: 2466114104@qq.com
}

Received: 2021.06.23; Accepted: 2021.09.10; Published: 2021.12.01

\begin{abstract}
Nowadays, Chinese convention and exhibition industry and tourism industry are in the rising period of development with more opportunities as well as various challenges. After reform and opening-up, conference and exhibition tourism began emerging in China, especially since the 21 st century. With the successful holding of international and professional exhibitions such as the 2008 Olympic Games, 2010 Shanghai World Expo, APEC annual meeting, Shanghai China International Industry Expo, one belt and one Road International Cooperation Summit Forum and Davos forum, MICE tourism has developed rapidly and made great contributions to Chinese economic growth and social progress. Based on the theory and research content, this paper designs a targeted questionnaire that is distributed on the Internet. Data from the questionnaire are collected and analyzed on the basic characteristics of the consumption behavior of MICE tourists in Shanghai. The results show that the main purpose of MICE tourists in Shanghai is to participate in exhibitions, and the time of shopping and sightseeing is shorter.
\end{abstract}

Keywords: MICE Tourism in Shanghai; Willingness of Travel; Economic Growth; Tourist Characteristics; Questionnaire

\section{Introduction}

Exhibition tourism is a form of tourism carried out by means of holding meetings, seminars, forums, and other conference activities as well as various exhibitions. It is a form of business tourism. It can be defined in broad and narrow sense. In a broad sense, MICE tourism refers to the tourism for the purpose of conferences and exhibitions, including various kinds of tourism and incentive tourism for work needs such as conference tourism and exhibition tourism. In a narrow sense, it refers to the economic activities that provide services outside the exhibition venue and related to tourism for the holding of conferences and exhibitions, and obtain certain income from them.

Chinese scholars mainly differentiate the concept of mice tourism from the perspective of tourism products and tourism industry. Zhou Chunfa defines MICE as a comprehensive form of tourism services, including holding various professional conferences, expo, and trade activities, cultural and sports events, scientific and technological exchanges, incentive tourism, etc. According to Sun Xianbo, MICE tourism is a comprehensive tourism product that takes conferences and exhibitions as its main attraction, takes tourism as its main form, and drives related industries such as food, accommodation, travel, travel, shopping, entertainment, etc. to achieve the benefits of the exhibition venue and meet the various needs of tourists. From the perspective of tourism industry, MICE tourism is the product of the integration of the convention and exhibition industry and tourism industry, and it is also an extension of the convention and exhibition industry in the tourism industry (Sun and Wang, 2020).

\section{Present Situation of Shanghai MICE Tourism Tourists}

According to the analysis of the Ministry of Commerce, PRC, as of 2017, Shanghai ranks first in China with 767 exhibitions and a total exhibition area of 16.89 million square kilometers, and it is also the only city 
in China with an exhibition area of over 10 million square meters. And the numbers are growing. Which is available for larger international exhibition venues have nine, respectively is: Shanghai National Convention and Exhibition Center, Shanghai New International Expo Center, Shanghai World Expo Exhibition and Convention Center, Shanghai Everbright Convention and Exhibition Center, Shanghai Mart, Shanghai Automobile Convention and Exhibition Center, Shanghai Exhibition Center, Shanghai Agricultural Exhibition Hall, Shanghai Changfeng Exhibition Center. This paper mainly studies the basic characteristics of the consumption behavior of the tourists who have participated in Shanghai convention and exhibition in recent years, and studies the demographic characteristics, consumption decision-making characteristics and actual consumption behavior of Shanghai convention and exhibition tourists. The general situation of Shanghai tourism and convention and exhibition industry is studied and sorted out.

The main indicators to measure the development of mice tourism in a city include exhibition area, exhibition number and economic benefits. In recent years, the number of exhibitions in Shanghai has been increasing every year, and the number of exhibitions has been increasing year by year, indicating that the development momentum of mice tourism in Shanghai is sufficient. The exhibition area has increased significantly in recent years. Shanghai is trying to promote the development of mice tourism to the large-scale and brand-oriented direction by expanding the exhibition plan. Reducing the amount and improving the quality is a feature of the development of mice tourism in Shanghai. In terms of economic benefits, the two indexes of direct income and stimulating consumption increase year by year, which will strengthen the direct driving effect of the tourism market and effectively promote the development of relevant industries such as "food, accommodation, travel, travel, shopping, entertainment" in Shanghai, and significantly increase the comprehensive benefits (Qin et al., 2021).

\section{Questionnaire Design}

Due to the limitation of time and environment, this paper could not carry out in-depth field investigation, so the questionnaire analysis method was adopted. With the help of Questionnaire Star mini program, the questionnaire was published on the Internet and the results were summarized.

The questionnaire has a total of 12 questions, roughly divided into three parts. The first part is the gender, age, education level, monthly income, and position analysis of the respondents. The second part is the channels of the respondents to obtain exhibition information, the purpose of tourism and the preference of scenic spots. The third part is the analysis of the respondents' actual consumption behaviors, including travel frequency, accommodation, and dining preferences. In the final online and offline statistics, a total of 120 questionnaires were issued (Han, 2021).

\subsection{Demographic Characteristics of MICE Tourists in Shanghai}

As shown in Table 1, the total number of respondents is 120, among which 75 are males. The number of people accounted for $62.5 \%$ of the total, and 45 women accounted for $37.5 \%$ of the total. According to the data analysis, most men and the minority of women participated in the exhibition, which is in line with the gender structure characteristics of modern business travel.

Table 1. Gender structure.

\begin{tabular}{ccc}
\hline & Frequency & Percentage \\
\hline Male & 75 & $62.5 \%$ \\
Female & 45 & $37.5 \%$ \\
\hline
\end{tabular}

As shown in Table 2, the total number of tourists coming to Shanghai to participate in the exhibition is 120, among which 9 persons aged 18 or below account for $7.5 \%, 55$ persons aged 18 to 25 account for $45 \%, 45$ persons aged 25 to 40 account for $37.5 \%$, and 7 persons aged 45 to 60 account for $5.8 \%$. Four people over 60 years old accounted for $3.3 \%$ of the total. According to the data analysis, the tourists aged 18-25 years old are the most, followed by those aged 25-40 years old. In conclusion, the age of MICE tourists in Shanghai is mainly between 18 and 40 years old, accounting for $82.5 \%$ of the total, indicating that young and middle-aged tourists in Shanghai occupy the main position. At the same time, it also shows that young and middle-aged people are more willing to accept new things and have a higher degree of cooperation with the questionnaire. Shanghai is 
an international metropolis, more popular with young people, exhibition is a dynamic industry, the survey shows that Shanghai exhibition tourists are mainly young and middle-aged in line with the actual situation.

Table 2. Age distribution.

\begin{tabular}{ccc}
\hline & Frequency & Percentage \\
\hline Under 18 & 9 & $7.5 \%$ \\
$18-25$ & 55 & $45.0 \%$ \\
$25-40$ & 45 & $37.5 \%$ \\
$40-60$ & 7 & $5.8 \%$ \\
More than 60 & 4 & $3.3 \%$ \\
\hline
\end{tabular}

As shown in Table 3, the total number of tourists who come to Shanghai to attend the exhibition is 120 people, among which 5 people who are below senior high school account for $4.1 \%$ of the total, 25 people with junior college education account for $20.8 \%$ of the total, and 90 people with bachelor degree or above account for $75 \%$. The education level of MICE tourists in Shanghai is concentrated in the middle and higher levels, and the general degree is high. However, this does not mean that the more educated people are, the more they know about the exhibition industry.

Table 3. Education background.

\begin{tabular}{ccc}
\hline & Frequency & Percentage \\
\hline High school and below & 5 & $4.1 \%$ \\
Junior College & 25 & $20.8 \%$ \\
Bachelor or above & 90 & $75 \%$ \\
\hline
\end{tabular}

As shown in Table 4, the total number of tourists coming to Shanghai to attend the exhibition is 120 people, among which 12 people with a monthly income of 2,000 yuan or less account for $10 \%$ of the total, 30 people with a monthly income of 2,000-6,000 yuan account for $25 \%$, and 78 people with a monthly income of more than 6,000 yuan account for 65\%.It can be seen that the monthly income of MICE tourists in Shanghai is mainly between 5,000-10,000 yuan, indicating that the MICE tourists in Shanghai are at the middle and high income level. Only a stable or high income can produce the willingness to travel, and the survey data is in line with the income of tourists.

Table 4. Monthly income.

\begin{tabular}{ccc}
\hline & Frequency & Percentage \\
\hline Below 2,000 & 12 & $10 \%$ \\
$2,000-6,000$ & 30 & $25 \%$ \\
Above 6,000 & 78 & $65 \%$ \\
\hline
\end{tabular}

\subsection{Consumer Behavior Decision of MICE Tourists in Shanghai}

As shown in Table 5, the total number of tourists who came to Shanghai to attend the exhibition was 120 , among which 35 were invited by the organizer, accounting for $29 \%$ of the total number; 27 were invited by media to obtain exhibition information, accounting for $22.5 \%$ of the total number; 32 were invited by peers, accounting for $26.6 \%$; and 26 were recommended by relatives, friends or colleagues, accounting for $21.7 \%$.It can be seen that the exhibition industry in Shanghai has paid a certain amount of efforts in publicity, to achieve a certain effect, all channels have been involved.

Table 5. Access to the exhibition information.

\begin{tabular}{ccc}
\hline & Frequency & Percentage \\
\hline Invited by the Organizer & 35 & $29.1 \%$ \\
Media Publicity & 27 & $22.5 \%$ \\
Invited by Peers & 32 & $26.6 \%$ \\
Recommended by Friends & 26 & $21.7 \%$ \\
\hline
\end{tabular}


It would be of great help to the tourism industry to know whether visitors would choose to visit, shop and entertain in Shanghai if they had enough time. As shown in Figure 1, 68.2\% of MICE tourists would choose to entertain, $32.5 \%$ of MICE tourists indicated that they might entertain, and only $9.3 \%$ of MICE tourists indicated that they would not entertain in Shanghai. Most MICE tourists will choose to visit Shanghai when they have enough time. The main reason for not planning to play is that they do not understand the relevant information and other objective factors. Most people are willing to and can spend money. This indicator is of vital importance to the development of tourism, and if fully utilized, it can increase certain tourism income for local tourism.

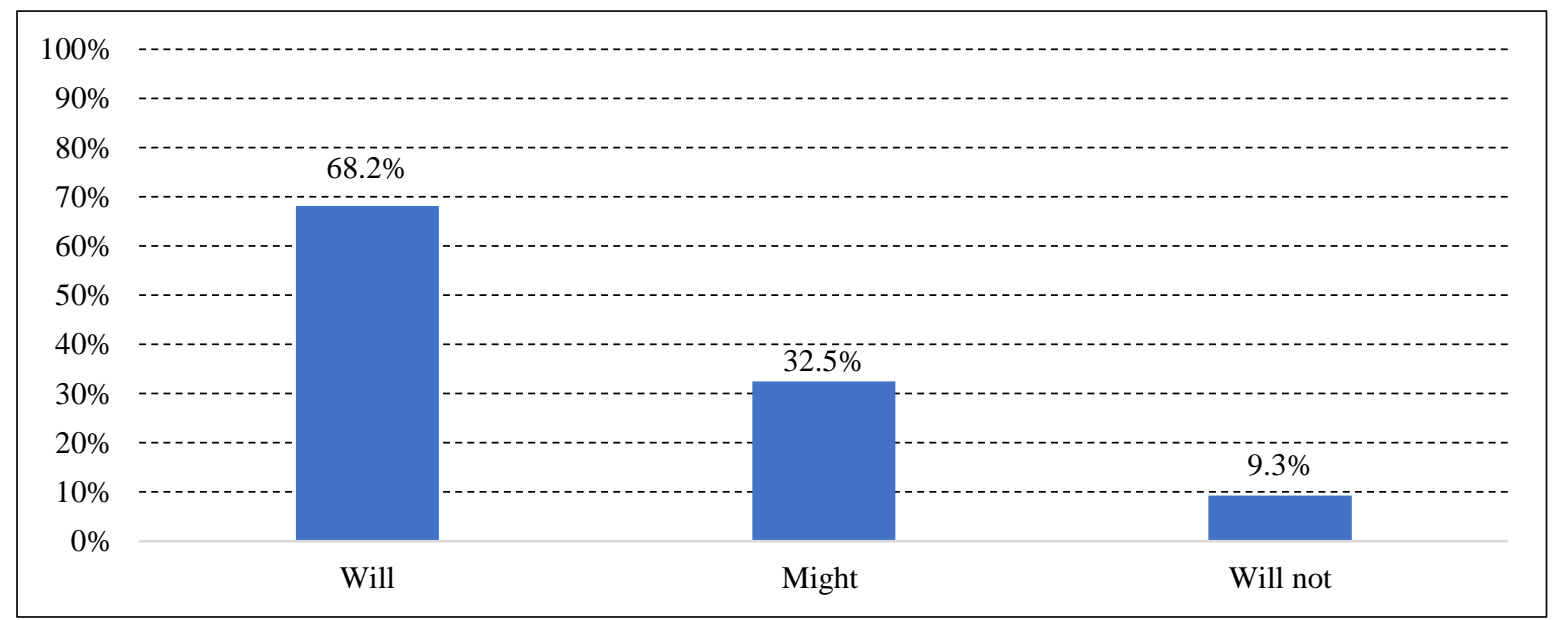

Figure 1. Willingness of travel in free time.

As shown in Figure 2, the main types of scenic spots preferred by MICE tourists in Shanghai are: theme parks $48 \%$, science and technology museums 51\%, landscapes $43 \%$, scenic spots $65 \%$ and other $20 \%$ respectively, and only $5 \%$ are not interested in them.

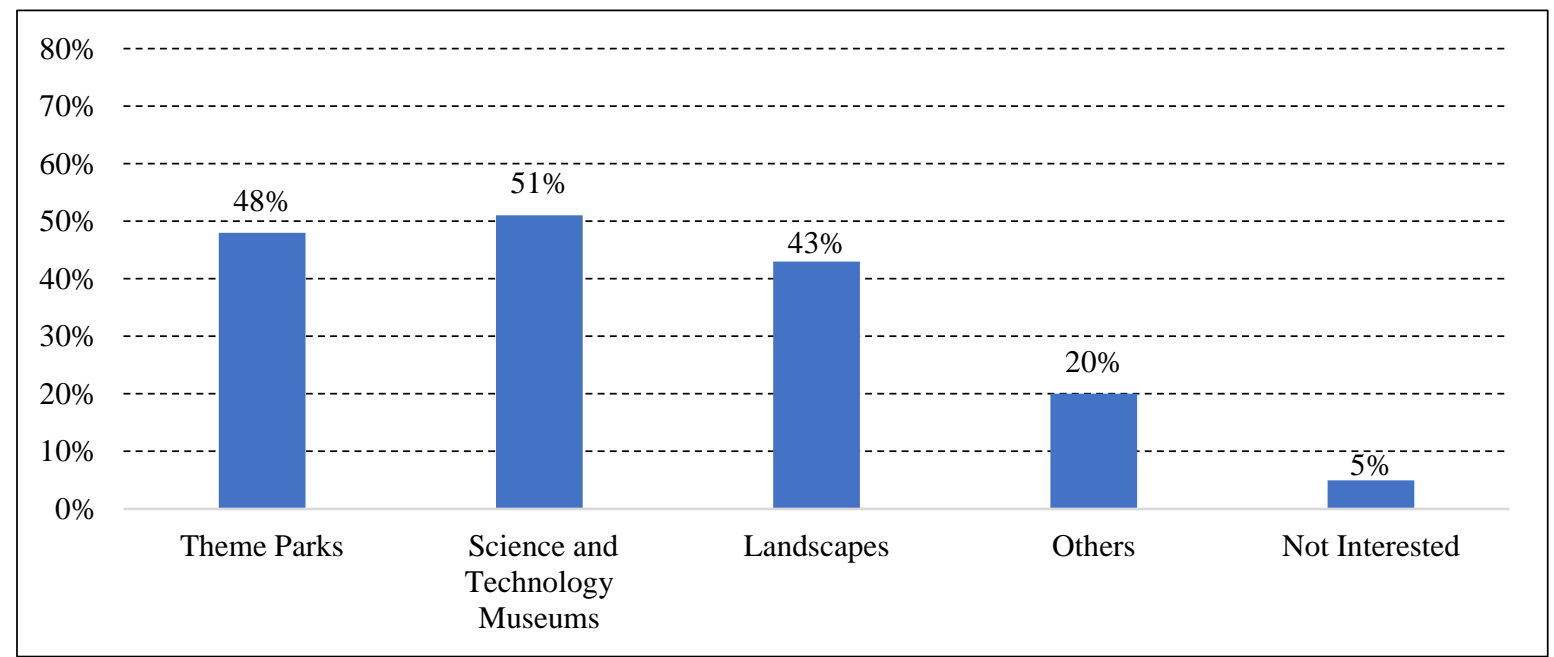

Figure 2. Preference of scenic spots.

As shown in Figure 3, 7\% of tourists have a total spending budget of less than 1,000 yuan, 25\% of them 1,000-2,500 yuan, 45\% of them 2,500-5,000 yuan and 23\% of them more than 5,000 yuan. More than half of MICE tourists have a total spending budget of more than 2,500 yuan. In general, the spending power of Shanghai MICE tourists is relatively strong, and the cost is also high. This directly reflects the economic contribution of MICE tourists to Shanghai and the economic benefits brought by MICE tourism. 


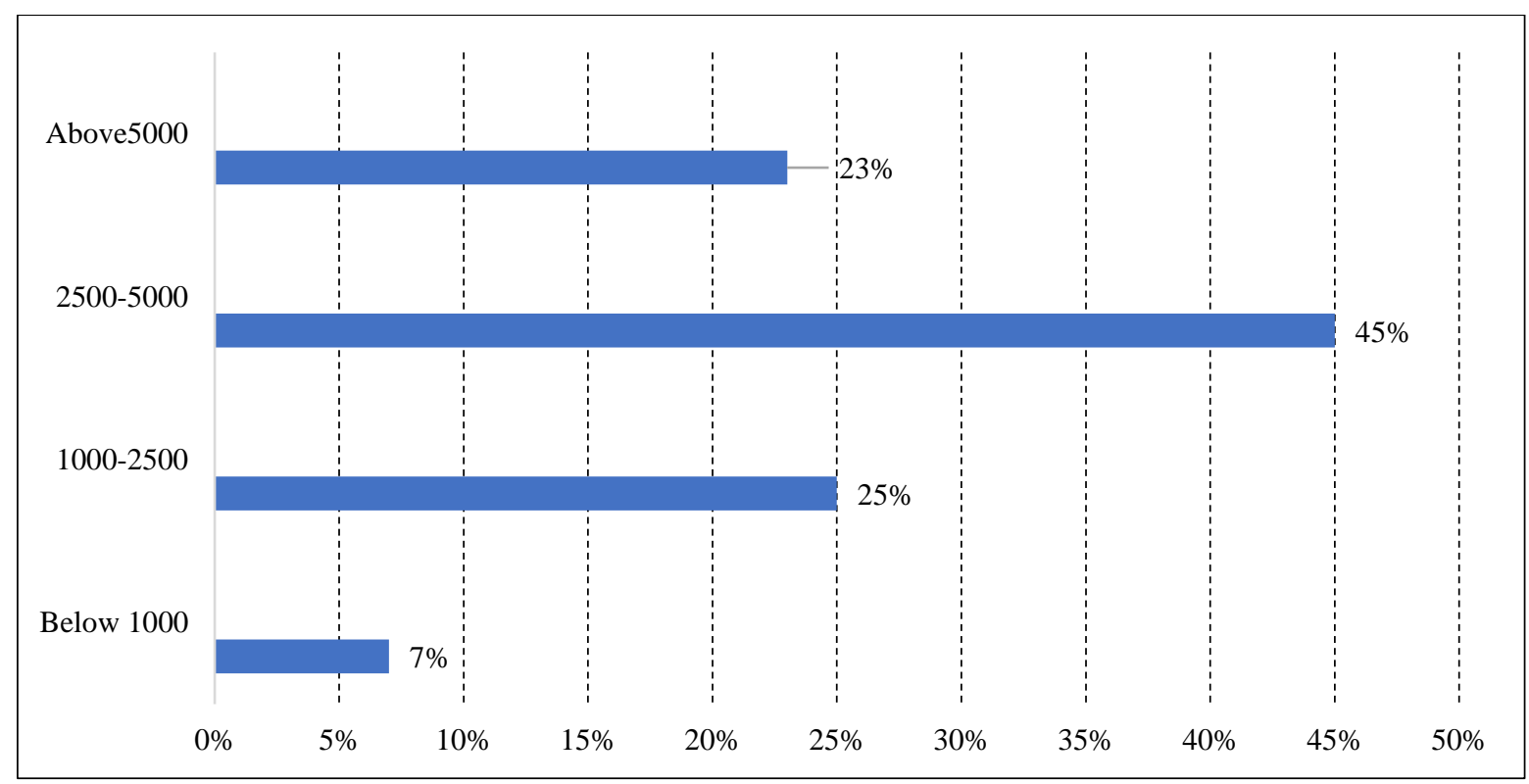

Figure 3. Total travel cost.

As shown in Table 6, through the investigation and analysis of the actual consumption content of MICE tourists in Shanghai, transportation, accommodation, and catering account for a large proportion, with the percentage of cases all exceeding 50\%, indicating that "food, accommodation and transportation" are the main consumption items of MICE tourists and the items that every traveling tourist must consume. Visiting, entertainment and shopping accounted for 52.5\%, 39.1\% and 31.5\% respectively, indicating that the three additional items of "tourism, shopping and entertainment" also accounted for a part of the consumption content, of which visiting and sightseeing accounted for more than half, indicating its importance.

Table 6. Content of tourism consumption.

\begin{tabular}{ccc}
\hline & Frequency & Percentage of cases \\
\hline Transportation & 78 & $57.7 \%$ \\
Accommodation & 86 & $62.5 \%$ \\
Catering & 57 & $52.3 \%$ \\
Visiting & 40 & $39.2 \%$ \\
Entertainment & 35 & $31.5 \%$ \\
Shopping & 22 & $18.8 \%$ \\
\hline
\end{tabular}

\subsection{Effects of Consumption of MICE Tourists in Shanghai}

As shown in Figure 4, the overall image, hotel services and transportation of Shanghai are all highly rated, all of which are over 9 points. Catering, exhibition facilities and exhibition services also scored above 8 points. The lowest degree of satisfaction is the climate environment, this may be because the weather in Shanghai changes a lot, with a big temperature difference in the morning and evening, which makes tourists not adapt to it for a while. 


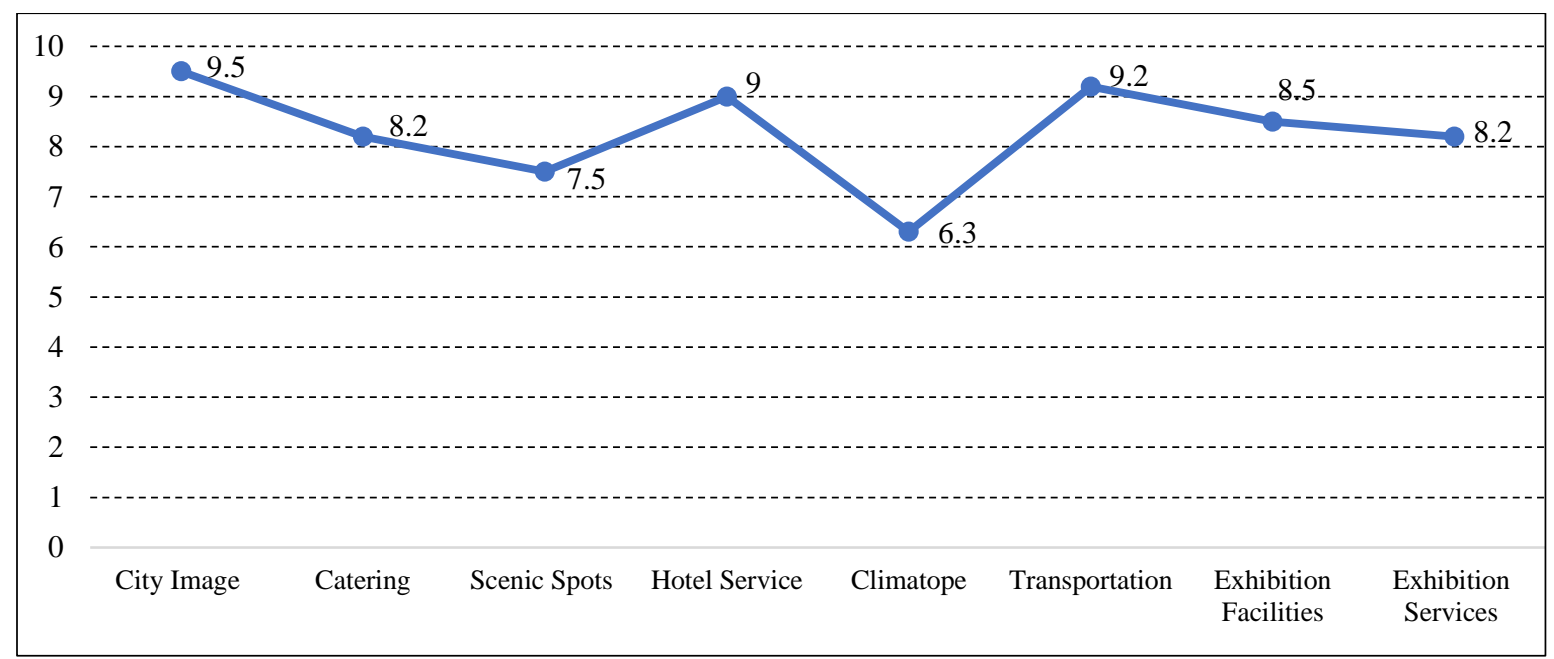

Figure 4. Satisfaction evaluation on various factors of MICE tourism.

\subsection{The Comprehensive Evaluation of Shanghai}

As shown in Figure 5, 45.48\% and 34.11\% of the overall evaluations of Shanghai are good, indicating that Shanghai MICE tourists have a relatively high overall evaluation of Shanghai and a good impression of the city. $13.99 \%$ rated it as not too bad. The poor ones accounted for $5.4 \%$, and the very poor ones only accounted for $0.87 \%$, or even less than $1 \%$, which indicates that the overall evaluation of Shanghai is good and the public praise is also very good. This is more conducive to the re-consumption of MICE tourists and is of great help to the development of MICE tourism in Shanghai.

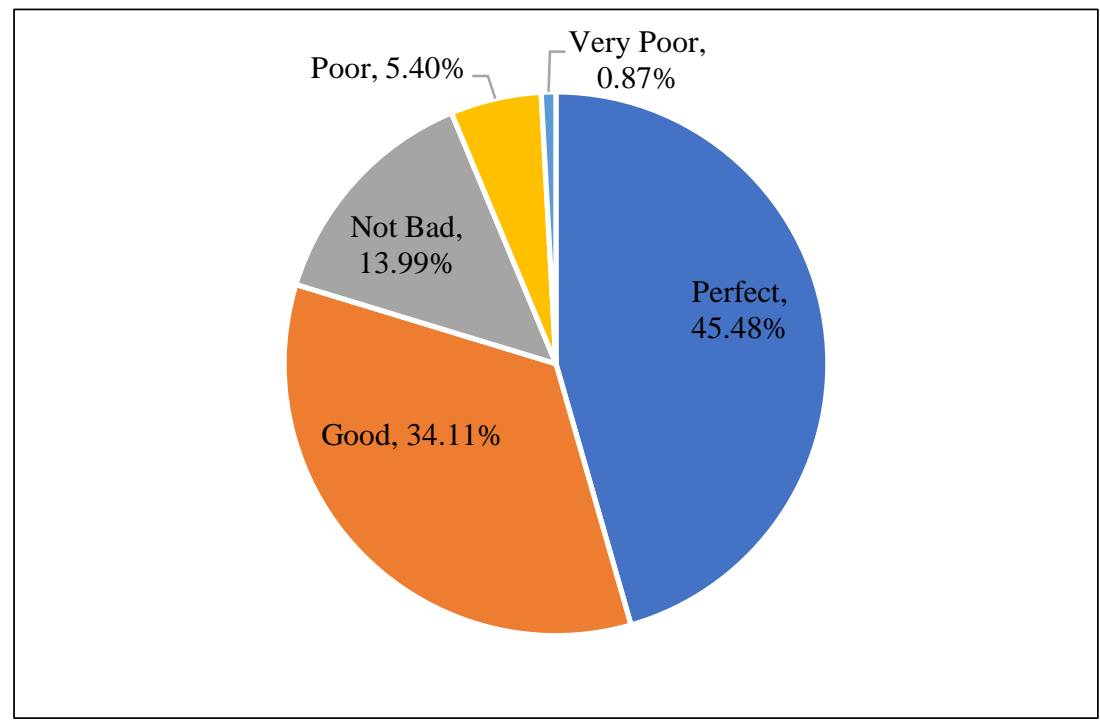

Figure 5. The comprehensive evaluation of Shanghai.

\subsection{Evaluation of Shanghai's Attractive Elements}

As shown in Figure 6, in the evaluation of Shanghai's attraction factors, MICE tourists in Shanghai think that the most attractive factor is Shanghai's economic vitality, accounting for $30.9 \%$. The second is the urban landscape of Shanghai, accounting for $26.82 \%$. Shanghai's urban landscape construction is indeed very distinctive and very famous. Cultural relics accounted for $14.58 \%$, indicating that Shanghai MICE tourists are more interested in this kind of tourist attractions in Shanghai. The construction of hotel facilities and services accounted for $7.58 \%$, indicating that Shanghai still needs to strengthen construction and improve in this respect. Shopping accounted for $7.29 \%$, entertainment $8.16 \%$ and other $4.66 \%$. Attractive factors can be used for reference to the development of cities and the construction of MICE tourism, and how to improve the tourism attraction is also a question worth thinking about. 


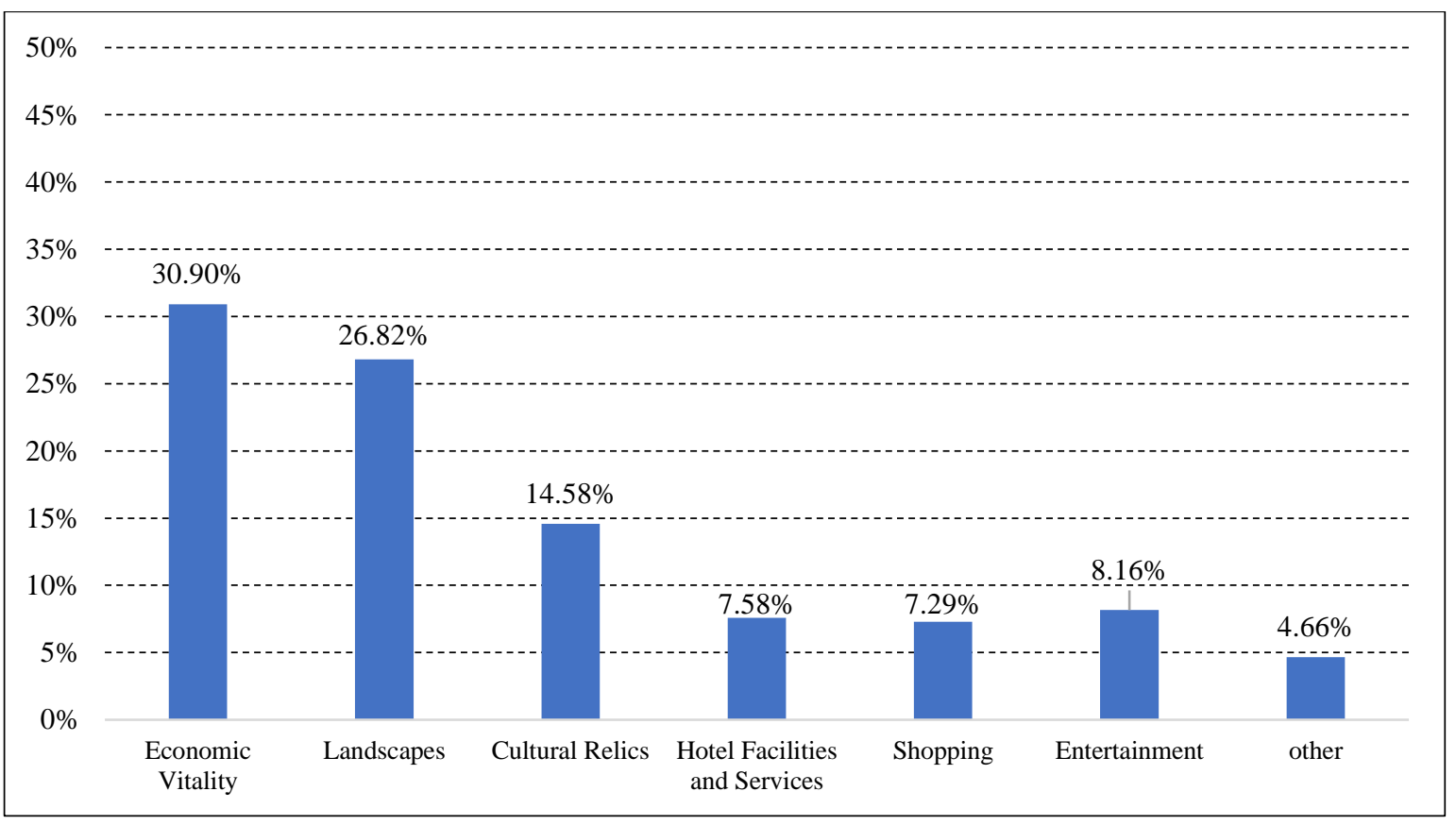

Figure 6. Evaluation of Shanghai's attractive elements.

\section{Conclusion}

Through the analysis and statistics of many data, the following conclusions are drawn in this survey:

Shanghai is attractive to convention and exhibition tourists and gives them a good impression. Exhibition tourists of different genders, different ages and different educational levels are generally interested in the tourist attractions in Shanghai, while the proportion of those who choose not to be interested or others is very small, which shows that the tourist attractions in Shanghai have a certain attraction for all MICE tourists. The city of Shanghai has its unique charm, some of which does not need rendering, but every visitor is deeply impressed. In the evaluation of attraction factors, the MICE tourists in Shanghai think that the most attractive factor is the economic vitality of Shanghai, followed by the urban landscape, which is the most unique charm of Shanghai, which is different from other cities. Exhibition tourists in Shanghai have a good impression on Shanghai and most of them are willing to repeat consumption. The frequency of MICE tourists in Shanghai is generally more than two times, which reflects that they are satisfied with the experience of traveling to Shanghai and have a good impression of Shanghai in all aspects. The MICE tourism in Shanghai has great prospects for development.

The image of a city can deepen people's unique charming image of the city through its unique characteristic buildings, tourist attractions, history, and culture, etc. For example, the bund, the most important landscape symbol in Shanghai; The Tiananmen Square in Beijing, which represents the image of China; Representing an era of Yan 'an Pagoda Mountain, the distinctive city often has the typical features of the visual landscape, such as the flag-raising ceremony in Tian'anmen Square, the hot pot in Chongqing, the Disney in Shanghai and so on. Bradley points out that city image plays a decisive role in attracting convention tourists, and that city image can also be used to enhance local visibility through influential councils or events (Wang et al., 2019).

Innovation is the key to maintain the development momentum of mice tourism destination. At present, there is a general lack of innovation in the convention and exhibition industry, which leads to the lack of staying power of convention and exhibition tourism. Therefore, the use of network platform to strengthen publicity and promotion is particularly important (Zheng, 2018). The MICE tourism in Shanghai is in the stage of steady development with favorable conditions in all aspects. Shanghai also has rich tourism resources. While developing itself, it should also deeply develop the surrounding tourism resources to achieve the effect of resource sharing. In terms of infrastructure, especially transportation, full attention should be paid to it. Time is very important for everyone, especially for busy exhibitors and visitors. Only by bringing MICE tourists to the exhibition site in the most convenient and efficient way can more people be retained for the exhibition. Only the continuous development of Shanghai convention and exhibition industry can promote the continuous development of MICE tourism. 


\section{References}

1. Han, X. (2021). Review of Dalian MICE Tourism Research. Tourism Overview, 7: 156-158.

2. Qin, P. Y., Chen, Y., \& Tu, J. (2021). Research on the Development Status and Countermeasures of MICE Tourism in Chongqing. Trade and Exhibition Economy, 7: 15-19.

3. Sun, S. J., \& Wang, Y. H. (2020). Analysis on Influencing Factors of Decision-making Behavior of Exhibition Tourists: A Case Study of Henan Province. Journal of Zhongyuan Institute of Technology, 31(6): 68-74.

4. Wang, Y., Shi, X. L., \& Kang, W. Q. (2019). Research on the Development of MICE Tourism. Green Science and Technology, 19: 241-243.

5. Zheng, H. J. (2018). Research on the Status and Development Countermeasures of MICE Tourism Destination in Guangzhou. Guilin University of Technology.

(Editor: Yiting Zeng) 